\title{
Article \\ The Spatial Heterogeneity of the Black Scorpionfish, Scorpaena porcus (Scorpaenidae): Differences in Length, Dietary and Age Compositions
}

\author{
Josipa Ferri ${ }^{1, *(D)}$ and Sanja Matić-Skoko ${ }^{2}$ (D) \\ 1 Department of Marine Studies, University of Split, 21000 Split, Croatia \\ 2 Institute of Oceanography and Fisheries, 21000 Split, Croatia; sanja@izor.hr \\ * Correspondence: josipa.ferri@unist.hr; Tel.: +385-215-58-195
}

Citation: Ferri, J.; Matić-Skoko, S. The Spatial Heterogeneity of the Black Scorpionfish, Scorpaena porcus (Scorpaenidae): Differences in Length, Dietary and Age Compositions. Appl. Sci. 2021, 11, 11919. https://doi.org/ 10.3390/app112411919

Academic Editor: Natalija Topić Popović

Received: 19 November 2021 Accepted: 13 December 2021 Published: 15 December 2021

Publisher's Note: MDPI stays neutral with regard to jurisdictional claims in published maps and institutional affiliations.

Copyright: (C) 2021 by the authors Licensee MDPI, Basel, Switzerland. This article is an open access article distributed under the terms and conditions of the Creative Commons Attribution (CC BY) license (https:// creativecommons.org/licenses/by/ $4.0 /)$.

\begin{abstract}
The present study assessed spatial variations in several biological characteristics of Scorpaena porcus Linnaeus, 1758 and estimated length structure, dietary composition and growth parameters for the species. Sampling was carried out in two areas, about $200 \mathrm{~km}$ apart, in the coastal Adriatic Sea, which is the northernmost region of the Mediterranean. A total of 388 specimens of S. porcus were caught, 233 from the Split area and 155 from the Pag Island area, and a higher proportion of individuals in the $\leq 15 \mathrm{~cm}$ length classes were found in the Split area. The results of the age, growth and diet analyses demonstrated that the black scorpionfish is a slow-growing and long-lived species that feeds on a wide variety of plant and animal taxa and shows a high selectivity for crustacean decapods. Detailed comparisons and multivariate analyses showed significant finescale spatial structuring of the investigated species, as observed length, dietary and age compositions were heterogeneous among the two areas. Fish from the Pag Island area ingested a greater diversity of the prey types, fed to a greater extent on fishes, reached the highest total length and showed a higher growth rate. Such intraspecific variations could reflect adaptations to different environmental conditions and support the geographical scale at which local black scorpionfish populations should be managed.
\end{abstract}

Keywords: growth rates; diets; location; intraspecific variation; multivariate analyses; Scorpaena porcus

\section{Introduction}

Scorpionfish are members of the family Scorpaenidae, one of the largest and most morphologically and ecologically diverse fish groups with more than 1400 species, distributed in many regions of the world, from shallow coastal waters to the deep sea [1,2]. They are mainly demersal species that are found on coral reefs in the tropical zones and on rocky shore grounds at high latitudes [3]. In the Mediterranean Sea, scorpionfish are a commercially important species, most common in hard-bottom and seagrass habitats where they have a critical ecological role [4].

The black scorpionfish, Scorpaena porcus Linnaeus, 1758 is one of the most common and numerous species of Scorpaenidae in the whole Mediterranean [5-7]. It is a benthic, nonmigratory coastal species of medium size, displaying nocturnal feeding behavior [8-11]. $S$. porcus mainly feed on benthic motile prey such as small fishes, crustaceans, and other invertebrates [6,12-14]. Compared with other Mediterranean scorpionfish species, the black scorpionfish is not a fast-growing and long-lived fish, with a maximum recorded age of 12 years [15]. However, the estimated life span for this species is highly variable among different areas of the fish's range, such as the Gulf of Gabès [16], Marmara Sea [17], Black Sea [18], and Adriatic Sea [19] where S. porcus attains 6, 7, 8, and 11 years of age, respectively. In the case of growth rates, comparison of theoretical growth models developed for the black scorpionfish also revealed differences across its geographical distribution [15]. These 
variabilities are possibly related to different environmental conditions and/or differences in fishing pressure in the aforementioned areas $[10,15]$.

Age composition and growth rates are flexible population parameters that can be selfregulated in accordance with heritable factors and environmental conditions [15]. The age structure of a fish population is a consequence of recruitment, growth, and elimination of individuals, while the growth rates determine the following processes: rates of recruitment and sexual maturity and the life span of the species [15]. Both parameters are essential in fisheries biology and management, e.g., in accessing fish population, stock structure, and their response to various aspects of management measures. Comparisons of the biological traits of fish species at different locations, including those in the Mediterranean, demonstrate that habitat characteristics, such as food, shelter, and density of predators, exert a powerful influence on age and growth patterns in a way that higher growth rates will occur in areas that offer better living conditions [20-24]. Consequently, the mix of fish from different areas within the range of the species may influence the estimate of the growth parameters and be an important source of 'noise' in fish age-length studies [24,25]. So, it is fundamental to reveal and understand possible intraspecific variations in these population parameters. Given that the black scorpionfish is a low home-range benthic species, investigating whether certain specific habitat characteristics, primarily food availability, influence the growth performance of this fish in different areas becomes very interesting. Moreover, the fact that observed spatial heterogeneity in S. porcus can help in preserving its populations, e.g., in a period of high fishing pressure [7,26], increases our interest in studying possible intraspecific variations in certain traits. During the present study, wide size ranges of the black scorpionfish were collected from the two different areas in the Adriatic Sea, the northernmost region of the Mediterranean. Data were recorded for certain biological characteristics of investigated scorpionfish species from the Split area and Pag Island area and then compared to determine the trends exhibited in those characteristics between the two sampling areas. Our focus was placed on testing whether the dietary and age-length compositions of $S$. porcus differ between the two areas and to what extent the age composition and growth rates are related to the habitat and food availability.

\section{Materials and Methods}

\subsection{Study Area and Sample Collection}

The black scorpionfish specimens were collected using sets of trammel nets; $1.5 \mathrm{~m}$ high and $32 \mathrm{~m}$ long 'poponica' trammel nets with inner layer mesh size of $28 \mathrm{~mm}$ and $150 \mathrm{~mm}$ mesh size of outer layers. Fish samples were captured in the nearshore, coastal waters of two sampling areas (Split area at $43.5^{\circ} \mathrm{N}$ and Pag Island at $44.4^{\circ} \mathrm{N}$, about $200 \mathrm{~km}$ apart) in the eastern Adriatic, at depths ranging between 10 and $40 \mathrm{~m}$. In both areas, biotopes were similar and characterized mainly by rocky substrata covered by photophilic algae alternating with patches of sand and Posidonia oceanica seagrass beds [7]. Both areas were also similar in terms of other environmental features, showing comparable trends for changes in temperature and salinity through the year [27]. During a 1-year study in 2008, fish were sampled monthly, and a total of $388 \mathrm{~S}$. porcus were caught.

After their capture, the black scorpionfish were measured to the nearest $0.1 \mathrm{~cm}$ total length (TL), weighed (W) to the nearest $0.1 \mathrm{~g}$, dissected, and eviscerated. Stomachs were fixed and preserved in a $4 \%$ neutral solution of formaldehyde and sea water, and sagittal otoliths were removed, cleaned, and stored dry in labeled envelopes. Total length and weight of individual collected fish specimens ranged from 8.2 to $28.1 \mathrm{~cm}$ (mean $\pm \mathrm{SD}$ $\mathrm{TL}=15.4 \pm 2.80 \mathrm{~cm}$ ) and from 12.3 to $493.3 \mathrm{~g}$ (mean $\pm \mathrm{SD} \mathrm{W}=81.4 \pm 53.90 \mathrm{~g}$ ), respectively.

\subsection{Laboratory Analyses}

For dietary analysis, stomach contents were examined, and the individual food organisms were sorted and identified to the lowest possible taxonomic level under a stereomicroscope, using field guides and taxonomic keys $[8,28]$. The number and weight (measured to 
the nearest $0.01 \mathrm{~g}$ ) of identified prey items were recorded after removing excess water with blotting paper.

For age and growth analysis, one otolith from each pair was selected at random, polished, and photographed with an Olympus DP-25 digital camera attached to a stereomicroscope, with reflected light against a dark background. Growth rings were visible as alternating opaque (appearing as light rings) and translucent (appearing as dark rings) zones, and ages were assigned to fish specimens based on their counts. Therefore, the combination of one opaque zone combined with one subsequent translucent zone was interpreted as one annulus, as already observed in this species [10]. Each otolith was read by the same reader, without auxiliary data on the fish size. A second reading was carried out 1 month later, and when readings differed by one or more years, a third reading was performed. If the difference still occurred, the otolith was discarded. We used images for age determination because their size and quality made it easier to interpret zoning pattern than direct observations under the stereomicroscope.

\subsection{Data Analyses}

Length frequency distributions of individuals from the two sampling areas were compared using the Kolmogorov-Smirnov two-sample test.

The cumulative number of prey taxa was plotted against the cumulative number of randomly pooled stomach samples, to measure sample size sufficiency in both sampling areas. To evaluate the rate of feeding activity, the vacuity index $\% \mathrm{~V}=(\mathrm{Ne} / \mathrm{Ns}) \times 100$ was calculated, where $\mathrm{Ne}$ is the number of empty stomachs and Ns is the total number of examined stomachs. The feeding diversity of the black scorpionfish was expressed by the Shannon-Wiener diversity index $\left(\mathrm{H}^{\prime}\right)$, using the abundance values of identified prey items [29]. The contribution of each prey taxa to the fish diet was evaluated by calculating the frequency of occurrence $(\% \mathrm{~F})$, as percentage of stomachs containing a particular prey taxon; abundance $(\% \mathrm{~N})$, as the number of each prey taxa expressed as a percentage of the total number of identified taxa; and weight $(\% \mathrm{~W})$, as weight of each prey taxa as a percentage of the total weight of prey ingested. These values were used to calculate: (i) the index of relative importance IRI $=(\% \mathrm{~N}+\% \mathrm{~W}) \times \% \mathrm{~F}$ [30]; (ii) coefficient of main food item $\mathrm{MFI}=[(\% \mathrm{~N}+\% \mathrm{~F}) / 2] \times(\% \mathrm{~W})[31]$; and (iii) the feeding coefficient $\mathrm{Q}=\% \mathrm{~N} \times \% \mathrm{~W}$, for each prey taxa. Prey were classified based on MFI values as follows: MFI $>75=$ preferential prey, $50<\mathrm{MFI}<75=$ main prey, $25<\mathrm{MFI}<50=$ secondary prey and MFI $<25=$ accessory prey. In addition, prey were also classified based on $Q$ values as follows: $Q>200=$ main prey, $20<\mathrm{Q}<200=$ secondary prey and $\mathrm{Q}<20=$ accessory prey.

Because each individual fish had often consumed only a few of all prey categories recognized in this study, stomachs of the samples from both areas were randomly sorted into groups of four to five, to decrease the number of prey categories with zero values in a sample. Dietary data for groups of individuals were then averaged, to produce a new series of replicates for the Split area and Pag Island area. The number of individuals in each new replicate depended on the total number of fishes in the sample. This approach followed one previously described and used for analyzing large dietary datasets for fishes $[32,33]$. Before multivariate analyses of dietary data, numerical composition data $(\mathrm{N})$ for 7 major dietary taxa of each replicate for the black scorpionfish from both areas were square-root transformed. These data were then used to construct a Bray-Curtis resemblance matrix, which was subjected to non-metric multidimensional scaling (nMDS) ordination and oneway analyses of similarities (ANOSIM), to determine whether the diets of this species from two separate areas were significantly different; and to permutational analysis of variance (PERMANOVA), to test whether there were interactions between the diet and the sampling area [34]. The magnitude of the global R-statistic value in the ANOSIM test was used to ascertain the extent to which diets of $S$. porcus differed between the two areas. In general, R-statistic values range from 1 , if the composition of all samples within each group are more similar to each other than to any of the samples from any other group, down to 0 if the average similarities between and within groups are the same [35]. The 
$p$ values $\leq 5 \%$ from both tests (ANOSIM and PERMANOVA) are referred to as significant. Similarity percentages (SIMPER) were used to determine which dietary categories typified the diets of S. porcus from both areas and which distinguished the diet of fish caught in the Split area from that of fish caught in the Pag Island area [35]. All multivariate analyses were performed using the routines in PRIMER 6, version 6.1.13 [34], in conjunction with PERMANOVA+, version 1.0.3 [36].

The von Bertalanffy growth model was fitted to the estimated age-length dataset using a non-linear least-square procedure of a Gauss-Newton algorithm. The von Bertalanffy growth parameters $\left(\mathrm{L}_{\infty}, \mathrm{K}\right.$, and $\left.\mathrm{t}_{0}\right)$ were calculated for each fish population sampled in the Split area and Pag Island area and compared by the multivariate Hotelling's $\mathrm{T}^{2}$-test [37]. The growth performance index $\left(\Phi^{\prime}=2 \log \mathrm{L}_{\infty}+\log \mathrm{K}\right)$ [38] was then calculated to compare the different populations of the black scorpionfish throughout its distribution range.

\section{Results}

Total length of the 233 individuals in the sample from the Split area ranged from 10.2 to $25.9 \mathrm{~cm}$ (mean $\pm \mathrm{SD} T L=15.1 \pm 2.8 \mathrm{~cm}$ ). The largest individual was sampled in the coastal waters of Pag Island $(28.1 \mathrm{~cm})$. Length-frequency distributions were significantly different between the two sampling areas (Kolmogorov-Smirnov test; $p=0.004$ ), with a higher proportion of individuals in the $\leq 15 \mathrm{~cm}$ length classes in the Split area (Figure 1 and Table 1).

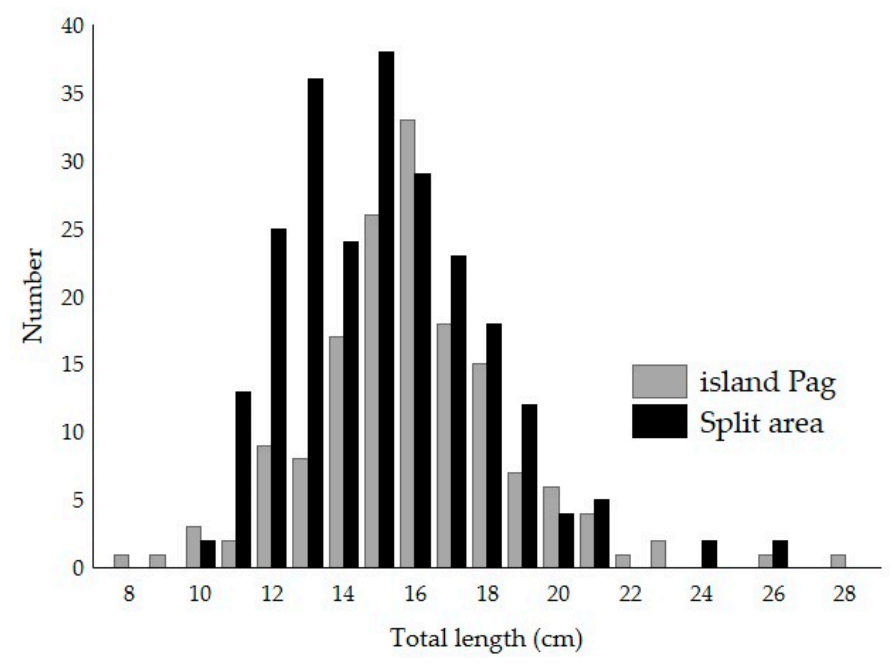

Figure 1. Length-frequency distribution of Scorpaena porcus in the Split area and Pag Island area, Adriatic Sea.

Table 1. Number, total length (TL) range, and mean total length with standard deviation (SD) of Scorpaena porcus in the Split area and Pag Island area, Adriatic Sea.

\begin{tabular}{ccc}
\hline & Split Area & Pag Island \\
\hline Number & 233 & 155 \\
TL range $(\mathrm{cm})$ & $10.2-25.9$ & $8.2-28.1$ \\
Mean TL \pm SD & $15.1 \pm 2.80$ & $15.9 \pm 2.90$ \\
\hline
\end{tabular}

\subsection{Overall Dietary Compositions}

The cumulative prey curves reached an asymptote with data for both areas, indicating that the number of stomachs analyzed per sampling area was sufficient to describe the diet of the black scorpionfish $\left(R^{2}=0.923\right.$ and $R^{2}=0.942$ for the best-fitting logistic curves for the Split area and Pag Island area, respectively). The food items were fresh in $44.1 \%$ and $46.6 \%$ of the stomachs analyzed in the Split area and Pag Island area, respectively. More empty stomachs and therefore, a higher vacuity index was found in the Split area $(26.3 \%$ 
compared to $6.8 \%$ in samples from the Pag Island area). On the contrary, in the samples from the Pag Island area, more of the contents in the stomachs were half-digested $(46.6 \%$ compared to $29.6 \%$ in the samples from the Split area). Values of the Shannon-Wiener diversity index for the samples from the Split area and Pag Island area were 2.35 and 2.90, respectively. It should be taken into consideration that, because of the degree of digestion of the prey, the determination of the species level was not always possible (Table 2).

Table 2. Frequency of occurrence $(\% \mathrm{~F})$, abundance $(\% \mathrm{~N})$, weight $(\% \mathrm{~W})$, index of relative importance (IRI), coefficient of main food item (MFI), and feeding coefficient (Q) of major taxa and all identified prey items in the diet of Scorpaena porcus in the Split area and Pag Island area, Adriatic Sea.

\begin{tabular}{|c|c|c|c|c|c|c|c|c|c|c|c|c|}
\hline \multirow[t]{2}{*}{$\begin{array}{l}\text { Major Taxa and Prey } \\
\text { Items }\end{array}$} & \multicolumn{2}{|c|}{$\% \mathrm{~F}$} & \multicolumn{2}{|c|}{$\% \mathbf{N}$} & \multicolumn{2}{|c|}{$\% W$} & \multicolumn{2}{|c|}{ IRI } & \multicolumn{2}{|c|}{ MFI } & \multicolumn{2}{|c|}{$\mathbf{Q}$} \\
\hline & $\begin{array}{l}\text { Split } \\
\text { Area }\end{array}$ & $\begin{array}{l}\text { Pag } \\
\text { Island }\end{array}$ & $\begin{array}{l}\text { Split } \\
\text { Area }\end{array}$ & $\begin{array}{l}\text { Pag } \\
\text { Island }\end{array}$ & $\begin{array}{l}\text { Split } \\
\text { Area }\end{array}$ & $\begin{array}{l}\text { Pag } \\
\text { Island }\end{array}$ & $\begin{array}{l}\text { Split } \\
\text { Area }\end{array}$ & $\begin{array}{l}\text { Pag } \\
\text { Island }\end{array}$ & $\begin{array}{l}\text { Split } \\
\text { Area }\end{array}$ & $\begin{array}{l}\text { Pag } \\
\text { Island }\end{array}$ & $\begin{array}{l}\text { Split } \\
\text { Area }\end{array}$ & $\begin{array}{l}\text { Pag } \\
\text { Island }\end{array}$ \\
\hline \multicolumn{13}{|l|}{ PHAEOPHYTA } \\
\hline Cystoseira sp. & 1.56 & 3.23 & 1.14 & 2.86 & 0.02 & 0.06 & 1.80 & 9.39 & 0.02 & 0.17 & 0.02 & 0.16 \\
\hline Total PHAEOPHYTA & 1.56 & 3.23 & 1.14 & 2.86 & 0.02 & 0.06 & 1.80 & 9.39 & 0.02 & 0.17 & 0.02 & 0.16 \\
\hline \multicolumn{13}{|l|}{ SPERMATOPHYTA } \\
\hline Posidonia oceanica & 18.75 & 8.06 & 13.64 & 7.14 & 7.88 & 0.83 & 403.46 & 64.29 & 127.62 & 6.30 & 104.47 & 5.92 \\
\hline $\begin{array}{c}\text { Total } \\
\text { SPERMATOPHYTA }\end{array}$ & 18.75 & 8.06 & 13.64 & 7.14 & 7.88 & 0.83 & 403.46 & 64.29 & 127.62 & 6.30 & 104.47 & 5.92 \\
\hline \multicolumn{13}{|l|}{ MOLLUSCA } \\
\hline Bittium reticulatum & - & 3.23 & - & 2.86 & - & 0.06 & - & 9.39 & - & 0.17 & - & 0.16 \\
\hline $\begin{array}{c}\text { Total Gastropoda } \\
\text { Bivalvia }\end{array}$ & - & 3.23 & - & 2.86 & - & 0.06 & - & 9.39 & - & 0.17 & - & 0.16 \\
\hline Glans trapezia & 1.56 & - & 1.14 & - & 0.19 & - & 2.08 & - & 0.26 & - & 0.22 & - \\
\hline Total Bivalvia & 1.56 & - & 1.14 & - & 0.19 & - & 2.08 & - & 0.26 & - & 0.22 & - \\
\hline \multicolumn{13}{|l|}{ Cephalopoda } \\
\hline Sepiolidae & - & 3.23 & - & 2.86 & - & 6.71 & - & 30.88 & - & 20.42 & - & 19.18 \\
\hline Total Cephalopoda & - & 3.23 & - & 2.86 & - & 6.71 & - & 30.88 & - & 20.42 & - & 19.18 \\
\hline Total MOLLUSCA & 1.56 & 3.23 & 1.14 & 5.71 & 0.19 & 6.77 & 2.08 & 40.27 & 0.26 & 30.26 & 0.22 & 38.68 \\
\hline \multicolumn{13}{|l|}{ ANNELIDA } \\
\hline Polychaeta sp. & 1.56 & - & 1.14 & - & 0.05 & - & 1.86 & - & 0.07 & - & 0.06 & - \\
\hline Total ANNELIDA & 1.56 & - & 1.14 & - & 0.05 & - & 1.86 & - & 0.07 & - & 0.06 & - \\
\hline \multicolumn{13}{|l|}{ ARTHROPODA } \\
\hline \multirow{2}{*}{\multicolumn{13}{|c|}{$\begin{array}{c}\text { Crustacea } \\
\text { Decapoda-Caridea }\end{array}$}} \\
\hline \multicolumn{6}{|l|}{ Decapoda-Caridea } & & & & & & & \\
\hline Palaemon xiphias & - & 1.61 & - & 1.43 & - & 0.03 & - & 2.35 & - & 0.04 & - & 0.04 \\
\hline Palaemon sp. & 1.56 & 1.61 & 1.14 & 1.43 & 0.91 & 1.35 & 3.20 & 4.49 & 1.23 & 2.06 & 1.04 & 1.93 \\
\hline $\begin{array}{l}\text { Palaemonidae } \\
\text { unidentified }\end{array}$ & - & 3.23 & - & 2.86 & - & 1.55 & - & 14.21 & - & 4.71 & - & 4.42 \\
\hline Processa edulis & - & 4.84 & - & 7.14 & - & 1.52 & - & 41.92 & - & 9.10 & - & 10.86 \\
\hline Processa sp. & 4.69 & 3.23 & 3.41 & 2.86 & 0.25 & 0.36 & 17.13 & 10.38 & 0.99 & 1.09 & 0.84 & 1.03 \\
\hline Processidae unidentified & 3.13 & 1.61 & 2.27 & 1.43 & 0.19 & 0.06 & 7.71 & 2.39 & 0.52 & 0.08 & 0.44 & 0.08 \\
\hline Total Caridea & 9.38 & 14.52 & 6.82 & 17.14 & 1.35 & 4.86 & 76.59 & 319.44 & 10.94 & 76.98 & 9.22 & 83.37 \\
\hline \multicolumn{13}{|l|}{ Decapoda-Anomura } \\
\hline Porcellana longicornis & 6.25 & - & 11.36 & - & 2.72 & - & 88.03 & - & 23.96 & - & 30.92 & - \\
\hline Galathea sp. & - & 3.23 & - & 2.86 & - & 0.50 & - & 10.82 & - & 1.51 & - & 1.42 \\
\hline Total Anomura & 6.25 & 3.23 & 11.36 & 2.86 & 2.72 & 0.50 & 88.03 & 10.82 & 23.96 & 1.51 & 30.92 & 1.42 \\
\hline \multicolumn{13}{|l|}{ Decapoda-Brachyura } \\
\hline Pisa armata & - & 1.61 & - & 1.43 & - & 1.69 & - & 5.02 & - & 2.56 & - & 2.41 \\
\hline Pisa sp. & - & 1.61 & - & 1.43 & - & 2.63 & - & 6.54 & - & 3.99 & - & 3.75 \\
\hline Macropodia sp. & - & 4.84 & - & 4.29 & - & 2.87 & - & 34.64 & - & 13.11 & - & 12.32 \\
\hline Cancer pagurus & 3.13 & - & 2.27 & - & 4.72 & - & 21.86 & - & 12.74 & - & 10.73 & - \\
\hline Cancer sp. & 1.56 & - & 1.14 & - & 2.86 & - & 6.25 & - & 3.86 & - & 3.25 & - \\
\hline Carcinus mediterraneus & 1.56 & - & 1.14 & - & 1.88 & - & 4.71 & - & 2.53 & - & 2.13 & - \\
\hline Liocarcinus sp. & 3.13 & 1.61 & 2.27 & 1.43 & 2.26 & 0.33 & 14.18 & 2.84 & 6.11 & 0.50 & 5.15 & 0.47 \\
\hline Pilumnus hirtellus & - & 1.61 & - & 1.43 & - & 3.54 & - & 8.01 & - & 5.38 & - & 5.05 \\
\hline Xantho poressa & 4.69 & 3.23 & 4.55 & 2.86 & 9.09 & 5.22 & 63.93 & 26.06 & 41.98 & 15.88 & 41.33 & 14.92 \\
\hline Xantho sp. & 20.31 & 3.23 & 17.05 & 2.86 & 36.84 & 4.39 & 1094.63 & 23.39 & 688.21 & 13.36 & 628.02 & 12.55 \\
\hline Xanthidae unidentified & - & 6.45 & - & 5.71 & - & 3.18 & - & 57.37 & - & 19.33 & - & 18.16 \\
\hline
\end{tabular}


Table 2. Cont.

\begin{tabular}{|c|c|c|c|c|c|c|c|c|c|c|c|c|}
\hline \multirow{2}{*}{$\begin{array}{c}\text { Major Taxa and Prey } \\
\text { Items }\end{array}$} & \multicolumn{2}{|c|}{$\% \mathrm{~F}$} & \multicolumn{2}{|c|}{$\% \mathbf{N}$} & \multicolumn{2}{|c|}{$\% W$} & \multicolumn{2}{|c|}{ IRI } & \multicolumn{2}{|c|}{ MFI } & \multicolumn{2}{|c|}{$\mathbf{Q}$} \\
\hline & $\begin{array}{l}\text { Split } \\
\text { Area }\end{array}$ & $\begin{array}{l}\text { Pag } \\
\text { Island }\end{array}$ & $\begin{array}{l}\text { Split } \\
\text { Area }\end{array}$ & $\begin{array}{l}\text { Pag } \\
\text { Island }\end{array}$ & $\begin{array}{l}\text { Split } \\
\text { Area }\end{array}$ & $\begin{array}{l}\text { Pag } \\
\text { Island }\end{array}$ & $\begin{array}{l}\text { Split } \\
\text { Area }\end{array}$ & $\begin{array}{l}\text { Pag } \\
\text { Island }\end{array}$ & $\begin{array}{l}\text { Split } \\
\text { Area }\end{array}$ & $\begin{array}{l}\text { Pag } \\
\text { Island }\end{array}$ & $\begin{array}{l}\text { Split } \\
\text { Area }\end{array}$ & $\begin{array}{l}\text { Pag } \\
\text { Island }\end{array}$ \\
\hline Eriphia verrucosa & 14.06 & 1.61 & 11.36 & 1.43 & 12.27 & 2.63 & 332.34 & 6.54 & 155.98 & 3.99 & 139.43 & 3.75 \\
\hline Portunus latipes & - & 1.61 & - & 1.43 & - & 1.63 & - & 4.93 & - & 2.48 & - & 2.33 \\
\hline Portunidae unidentified & 1.56 & - & 1.14 & - & 0.81 & - & 3.04 & - & 1.09 & - & 0.92 & - \\
\hline Brachynotus sp. & 4.69 & 11.29 & 3.41 & 10.00 & 7.13 & 14.12 & 49.39 & 272.32 & 28.85 & 150.31 & 24.30 & 141.19 \\
\hline Brachyura unidentified & 14.06 & 14.52 & 11.36 & 15.71 & 4.46 & 16.14 & 222.50 & 462.36 & 56.68 & 243.91 & 50.66 & 253.58 \\
\hline $\begin{array}{c}\text { Total Brachyura } \\
\text { Isopoda }\end{array}$ & 75.00 & 53.23 & 55.68 & 50.00 & 82.48 & 58.36 & 10362.29 & 5767.48 & 5389.45 & 3012.06 & 4592.75 & 2917.90 \\
\hline Isopoda sp. & 3.13 & - & 5.68 & - & 0.77 & - & 20.17 & - & 3.40 & - & 4.39 & - \\
\hline Total Isopoda & 3.13 & - & 5.68 & - & 0.77 & - & 20.17 & - & 3.40 & - & 4.39 & - \\
\hline Total Crustacea & 87.50 & 70.97 & 79.55 & 70.00 & 87.17 & 63.72 & 14587.49 & 9489.75 & 7280.57 & 4491.18 & 6933.87 & 4460.30 \\
\hline Total ARTHROPODA & 87.50 & 70.97 & 79.55 & 70.00 & 87.17 & 63.72 & 14587.49 & 9489.75 & 7280.57 & 4491.18 & 6933.87 & 4460.30 \\
\hline \multicolumn{13}{|l|}{ ECHINODERMATA } \\
\hline Echinoidea sp. & 1.56 & - & 1.14 & - & 0.26 & - & 2.19 & - & 0.36 & - & 0.30 & - \\
\hline $\begin{array}{c}\text { Total } \\
\text { ECHINODERMATA }\end{array}$ & 1.56 & - & 1.14 & - & 0.26 & - & 2.19 & - & 0.36 & - & 0.30 & - \\
\hline \multicolumn{13}{|l|}{ PISCES } \\
\hline Symphodus melanocercus & - & 1.61 & - & 1.43 & - & 1.71 & - & 5.07 & - & 2.61 & - & 2.45 \\
\hline Symphodus sp. & - & 3.23 & - & 2.86 & - & 5.42 & - & 26.69 & - & 16.47 & - & 15.47 \\
\hline Gobius sp. & - & 1.61 & - & 1.43 & - & 5.50 & - & 11.17 & - & 8.36 & - & 7.86 \\
\hline Atherina hepsetus & - & 1.61 & - & 1.43 & - & 4.61 & - & 9.75 & - & 7.02 & - & 6.59 \\
\hline Pisces unidentified & 3.13 & 6.45 & 2.27 & 7.14 & 4.42 & 11.38 & 20.93 & 119.53 & 11.94 & 77.38 & 10.05 & 81.32 \\
\hline Total PISCES & 3.13 & 14.52 & 2.27 & 14.29 & 4.42 & 28.63 & 20.93 & 622.92 & 11.94 & 412.25 & 10.05 & 408.95 \\
\hline
\end{tabular}

In total, 37 identified prey items, belonging to seven major taxa (Phaeophyta, Spermatophyta, Mollusca, Annelida, Arthropoda, Echinodermata, Pisces), were fully identified in the stomachs of the black scorpionfish from both areas (Table 2). Among the major prey groups, arthropods, specifically crustaceans ( 25 taxa in total), emerged as the dominant group by all three dietary indices in both sampling areas. The second and third most important groups in the diet of S. porcus were Spermatophyta $(\% \mathrm{~F}=18.75, \% \mathrm{~N}=13.64, \% \mathrm{~W}=7.88)$ and Pisces $(\% \mathrm{~F}=3.13, \% \mathrm{~N}=2.27, \% \mathrm{~W}=4.42)$ in the Split area and Pisces $(\% \mathrm{~F}=14.52$, $\% \mathrm{~N}=14.29, \% \mathrm{~W}=28.63)$ and Spermatophyta $(\% \mathrm{~F}=8.06, \% \mathrm{~N}=7.14, \% \mathrm{~W}=0.83)$ in the Pag Island area, respectively. Among crustaceans, Xantho sp. and an unidentified Brachyura species prevailed in terms of frequency of occurrence, abundance, and weight in the Split area and Pag Island area, respectively. Therefore, with respect to the index of relative importance, Xantho sp. and an unidentified Brachyura species were the most important prey categories in the Split area and Pag Island area, respectively. Regarding the coefficient of the main food item, Xantho sp. (688.21), Eriphia verrucosa (155.98), and P. oceanica (127.62), were preferential prey for the fish from the Split area (Table 2). On the other hand, these prey categories were accessory prey for the fish from the Pag Island area, and the preferential prey for the fish from this area were an unidentified Brachyura species (243.91), Brachynotus sp. (150.31) and Pisces unidentified (77.38). Regarding the feeding coefficient, the main prey for the fish from the Split area was Xantho sp. (628.02), and for the fish from the Pag Island area, an unidentified Brachyura species (253.58) (Table 2).

\subsection{Age-Length Compositions and Growth Rates}

The inner structure of sagittal otoliths of the black scorpionfish consisted of a wide opaque nucleus, surrounded by an alternating pattern of translucent and opaque zones. Of the 388 obtained otoliths, age counts were successfully agreed for 274 otoliths $(70.6 \%)$, and the remaining 114 otoliths (29.4\%) were discarded. The age-length composition estimated for fish caught in the Split area and Pag Island area is summarized in Table 3. In the Split area, most fish $(76.8 \%)$ were estimated to be $2-5$ years old, with a maximum age of 12 years. In the Pag Island area, $73.9 \%$ of aged specimens were between 3 and 5 years, with a maximum age of 11 years. 
Table 3. Age-length keys of Scorpaena porcus in the Split area and Pag Island area, Adriatic Sea.

\begin{tabular}{|c|c|c|c|c|c|c|c|c|c|c|c|c|c|c|c|c|c|c|c|c|c|c|c|c|}
\hline \multirow[b]{2}{*}{ TL (cm) } & \multicolumn{12}{|c|}{ Split Area } & \multicolumn{12}{|c|}{ Pag Island } \\
\hline & 1 & 2 & 3 & 4 & 5 & 6 & 7 & 8 & 9 & 10 & 11 & 12 & 1 & 2 & 3 & 4 & 5 & 6 & 7 & 8 & 9 & 10 & 11 & 12 \\
\hline 8 & & & & & & & & & & & & & 1 & & & & & & & & & & & \\
\hline 9 & & & & & & & & & & & & & 1 & & & & & & & & & & & \\
\hline 10 & 2 & & & & & & & & & & & & 3 & & & & & & & & & & & \\
\hline 11 & 10 & 3 & & & & & & & & & & & 2 & & & & & & & & & & & \\
\hline 12 & & 7 & 15 & 1 & & & & & & & & & 2 & 3 & 1 & & & & & & & & & \\
\hline 13 & & 10 & 7 & 11 & 1 & & & & & & & & & 1 & 4 & & & & & & & & & \\
\hline 14 & & 1 & 4 & 7 & 2 & & & & & & & & & & 6 & 5 & 1 & & & & & & & \\
\hline 15 & & 1 & 5 & 9 & 2 & 1 & & & & & & & & 1 & 11 & 6 & & 1 & & & & & & \\
\hline 16 & & & 1 & 7 & 6 & & & & & & & & & & 6 & 5 & 6 & & 2 & & & & & \\
\hline 17 & & & & 3 & 5 & 1 & & 2 & & & & & & & & 8 & 4 & 1 & 1 & & & & & \\
\hline 18 & & & & 2 & 3 & 1 & 1 & & 1 & & & & & & & 3 & 8 & 2 & 2 & & & & & \\
\hline 19 & & & & 3 & 2 & 4 & 2 & & & & & & & & & 1 & 5 & 1 & & & & & & \\
\hline 20 & & & & & & 1 & & 2 & & 1 & & & & & & & 6 & & & & & & & \\
\hline 21 & & & & & 1 & 2 & 1 & & & & & & & & & & 1 & 3 & 1 & & & & & \\
\hline 22 & & & & & & & & & & & & & & & & & & & 1 & & & & & \\
\hline $\begin{array}{l}22 \\
23\end{array}$ & & & & & & 1 & & & & & & & & & & & 1 & & & & & & & \\
\hline 24 & & & & & & & & 1 & & & & & & & & & & & & & & & & \\
\hline 25 & & & & & & & & & & & & & & & & & & & & & & & & \\
\hline 26 & & & & & & & & 1 & & & & 1 & & & & & & & & 1 & & & & \\
\hline 28 & & & & & & & & & & & & & & & & & & & & & & & 1 & \\
\hline $\mathrm{N}$ & 12 & 22 & 32 & 43 & 22 & 11 & 4 & 6 & 1 & 1 & 0 & 1 & 9 & 5 & 28 & 28 & 32 & 8 & 7 & 1 & 0 & 0 & 1 & 0 \\
\hline$\%$ & 7.8 & 14.2 & 20.7 & 27.7 & 14.2 & 7.1 & 2.6 & 3.9 & 0.6 & 0.6 & 0 & 0.6 & 7.6 & 4.2 & 23.5 & 23.5 & 26.9 & 6.8 & 5.9 & 0.8 & 0 & 0 & 0.8 & 0 \\
\hline
\end{tabular}

The von Bertalanffy growth curves were fitted to age-length datasets estimated for fish from the Split area and Pag Island area (Figure 2). Estimated parameters for S. porcus from the Split area and Pag Island area were $\mathrm{L}_{\infty}=60.94 \mathrm{~cm}, \mathrm{~K}=0.03$ year $^{-1}, \mathrm{t}_{0}=-5.18$ year $\left(\mathrm{R}^{2}=0.83\right)$ and $\mathrm{L}_{\infty}=41.99 \mathrm{~cm}, \mathrm{~K}=0.06$ year $^{-1}, \mathrm{t}_{0}=-3.54$ year $\left(\mathrm{R}^{2}=0.84\right)$, respectively. The growth performance index $\left(\Phi^{\prime}\right)$ was 2.05 for the fish from the Split area and 2.02 for the fish from the Pag Island area.

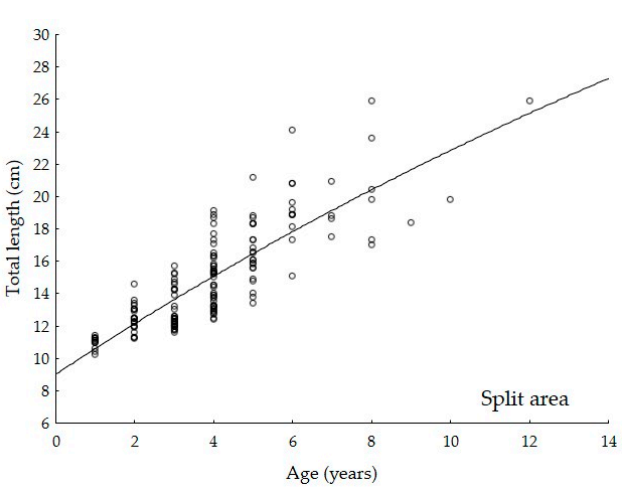

(a)

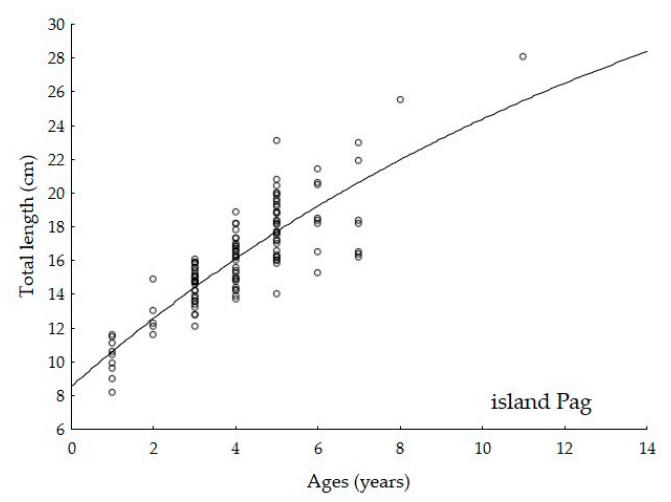

(b)

Figure 2. Fitted von Bertalanffy growth curves of Scorpaena porcus in: (a) Split area and (b) Pag Island area, Adriatic Sea.

\subsection{Intraspecific Comparisons between Dietary and Age-Length Compositions in the Two Areas}

Following nMDS ordination, the dietary samples for the black scorpionfish in the Split area and Pag Island area formed groups on the plot (Figure 3). Thus, samples from the Split area formed a group that lies below those from the Pag Island area. Oneway ANOSIM demonstrated that, although the dietary compositions of the fish differed significantly among sampling areas $(p=0.001)$, the global R-statistic value was low at 0.294. PERMANOVA showed that the dietary composition of the black scorpionfish was significantly related to the sampling area $(p=0.001)$ (Table 4$)$. SIMPER emphasized that arthropods were important contributors to the diet of S. porcus in both areas and that dietary compositions differed by $35.85 \%$ between the Split area and Pag Island area. Groups Pisces and Spermatophyta accounted for more than $52 \%$ of the dissimilarities between the 
two areas, and when we include Arthropods as the third major contributor, all of them accounted together for more than $70 \%$.

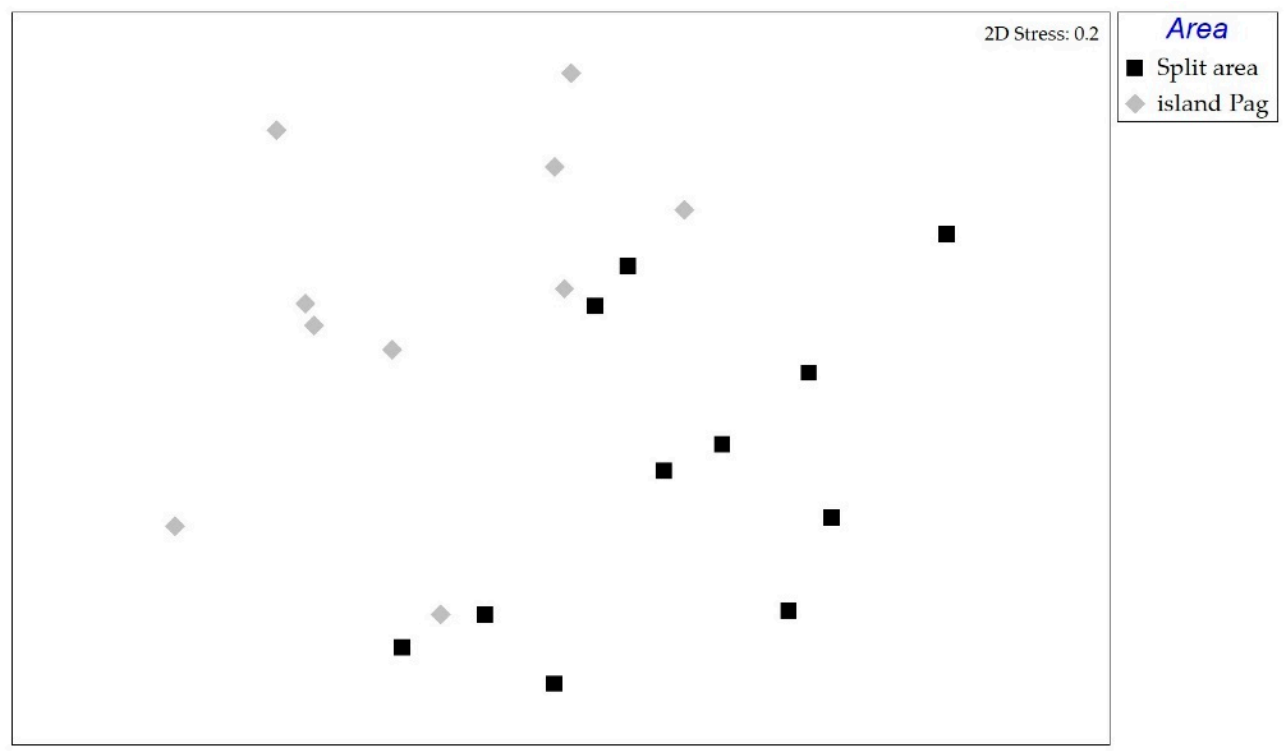

Figure 3. nMDS ordination of the dietary compositions of Scorpaena porcus in the Split area and Pag Island area, Adriatic Sea.

Table 4. Summary of PERMANOVAs on the dietary compositions of Scorpaena porcus in the Split area and Pag Island area, Adriatic Sea, testing for the effect of the area.

\begin{tabular}{cccccc}
\hline Source of Variation & df & SS & MS & Pseudo-F & $P$ (Perm) \\
\hline Area & 1 & 2717.6 & 2717.6 & 5.276 & 0.001 \\
Residuals & 19 & 9786.5 & 515.08 & & \\
Total & 20 & 12504 & & & \\
\hline
\end{tabular}

The Hotelling's $\mathrm{T}^{2}$-test indicated that the von Bertalanffy growth curves differed significantly between the two populations tested $\left(T^{2}=766.36>T^{2}{ }_{0}(0.05,3270)=11.87\right)$. The $\mathrm{L}_{\infty}$ value was higher in fish from the Split area, and the $\mathrm{K}$ value was higher in fish from the Pag Island area. Therefore, considering the growth coefficient, fish from the Pag Island area grew faster than fish from the Split area. On the other hand, no statistical difference in length-at-age data (Table 5) derived from the von Bertalanffy growth curves was observed between the two populations ( $t$-test for paired comparison, $p=0.749$ ).

Table 5. Estimates of length-at-age of Scorpaena porcus in the Split area and Pag Island area, Adriatic Sea.

\begin{tabular}{ccc}
\hline Age (Years) & \multicolumn{2}{c}{ Length-at-Age $(\mathbf{c m})$} \\
\hline & Split Area & Pag Island \\
\hline 1 & 10.9 & 10.2 \\
3 & 12.5 & 12.8 \\
4 & 13 & 14.5 \\
5 & 14.9 & 16.1 \\
6 & 16.6 & 18.1 \\
7 & 19.2 & 18.7 \\
8 & 18.9 & 18.7 \\
9 & 20.7 & 25.5 \\
10 & 18.4 & - \\
11 & 19.8 & - \\
12 & - & 28.1 \\
\hline
\end{tabular}




\section{Discussion}

The quantitative data were collected for the black scorpionfish using the same sampling methods and at comparable depths in two different areas located in coastal waters and with similar biotopes demonstrating variations in certain biological characteristics. They were found to occur at a finer spatial scale (about $200 \mathrm{~km}$ ) in the eastern Adriatic Sea than has been shown elsewhere in the Mediterranean [10,15]. First of all, our results revealed spatial variation in length structure of S. porcus, as we found that smaller individuals caught in the Split area were more abundant than those caught in the Pag Island area. Length is a biological trait that responds to local conditions [39], so observed variation could be linked to some specific habitat characteristics. This is not unusual if we have in mind that S. porcus has evolved high site fidelity [4]. In general, habitat characteristics are important in explaining local abundance patterns of benthic fish species, such as the investigated scorpionfish, but are difficult to control $[7,40]$.

As well as influence on local fish abundance, habitat characteristics may also alter the patterns of distribution and abundance of different types of prey in the environment and consequently the relative abundance of prey taxa that are ingested by fish. This could account for our finding that the diversity of the food types ingested by the black scorpionfish in the Pag Island was greater than that of the same species in the Split area. In general, variations by area in the studies on fish diet are commonly related to differences in availability of resources in each area [41,42]. The findings on dietary compositions emphasize that in two different areas that were the subject of the present study, S. porcus feeds on a wide variety of plant and animal taxa, as it does in areas elsewhere in the Mediterranean [6,12-14]. This, together with observed high selectivity for crustacean decapods, is a widespread feeding behavior in Scorpaenidae species in general [12]. The black scorpionfish ingested brown algae, spermatophytes, mollusks, arthropods, and fishes in both areas. However, within the major taxa, the contributions of the various dietary categories differed between areas. In terms of abundance, this scorpionfish consumed relatively more spermatophytes and arthropods in the Split area than in the Pag Island area, while specimens from the Pag Island area fed to a greater extent on other fishes. Moreover, Anomura (precisely Porcellana longicornis) and Brachyura (precisely Xantho sp.) species were ingested in substantial amounts by S. porcus in the Split area, and fishes from Pag Island consumed more Caridea (precisely Processa edulis) species. These data demonstrate that the black scorpionfish is a generalist and opportunistic feeder, which might have played an important role in the success of this species in a wide range of areas in the Mediterranean [43]. Furthermore, the statistical tests employed in this study emphasized that the dietary composition of S. porcus in the Split area was significantly different from that in the Pag Island area. Two dietary categories, namely spermatophytes and fishes, were the most important of dietary categories for distinguishing between the diets of fish in the Split area from those in the Pag Island area. In addition, arthropods were also important in distinguishing the diet of $S$. porcus, so Xantho sp. and an unidentified Brachyura species were contributors to the diet of this species in the Split area and Pag Island area, respectively. Such results, as previously mentioned and already documented for other fish species worldwide, could be related to variations in the spatial availability of the different types of prey in the environment [42].

The maximum age of $S$. porcus estimated in this study was 12 years (fish from the Split area), being equal to the maximum age cited by Kutsyn et al. [15], using the same method and a similar fish length range. This value is higher than those reported in most other studies in different Mediterranean areas [16-19]. Regarding the estimated parameters of the von Bertalanffy growth curves, a low estimate of $\mathrm{K}$, together with a high $\mathrm{L}_{\infty}$ in both areas, indicates that the black scorpionfish is a slow-growing and long-lived species. Growth curves constructed for fish from the Split area and Pag Island area revealed a significantly different age structure for S. porcus in the Adriatic. In the Pag Island area, we found only one individual older than 8 years. In addition, almost $59 \%$ of the catch in the Pag Island area comprised the first four age classes $\left(0^{+}\right.$to $\left.4^{+}\right)$, whereas in the Split area 
the same age classes made up more than $70 \%$ of the catch. The large variation in results also can be observed on a larger spatial scale, when comparing the growth parameters for the black scorpionfish obtained by different authors $[10,15]$. By calculating the growth performance index, our results showed somewhat slower growth rates than those reported in other areas $[15,19,44,45]$. These differences throughout the Mediterranean indicated population separation and may be a consequence of different (i) latitudes, (ii) environmental conditions, (iii) size distribution of sampled fish (heterogeneity of the sample), and (iv) fishing pressures.

The substantial length range of the black scorpionfish over both investigated coastal areas in the Adriatic demonstrates that environmental conditions in these two areas are highly favorable for sustaining populations of this species and that their requisite food resources are abundant. Regardless, S. porcus showed significant spatial structuring, as observed length, dietary, and age compositions were heterogeneous among the two areas. Contributions of the individual prey species seemed to benefit these scorpionfish populations in terms of maximum size and growth performance. Fish from the Pag Island area ingested a greater diversity of prey types, had a specific dietary composition, reached the highest $\mathrm{TL}$, and showed a higher growth rate. The growth rate depends on a variety of local abiotic factors such as temperature, levels of dissolved oxygen and ammonia, salinity, photoperiod, food availability, and quality [21], and we are aware that the latter is just one of them. Most studies have focused on temperature, due to its known effect on fish metabolism, and have shown that the growth rate of a species is generally lower at higher and cooler latitudes than at lower and warmer latitudes [46-48]. Additional research should, therefore, identify all variables that are most likely to influence $S$. porcus populations in different areas and should quantify their relative influence on fish biology, specifically growth rates. However, our results highlight the need to understand the relative contributions of such area-specific data. The importance of considering the spatial stratification of the S. porcus population and the variability of its biological traits is emphasized. As information on spatial ecology is necessary for effective management and conservation of fish populations, we recommend managing the black scorpionfish in the Mediterranean as separate management units. At the same time, analysis of long-term data showed that the Adriatic population of S. porcus did not go through profound changes [7], so the results of this study imply that the observed variability in traits reflects adaptations of this species to different conditions that have enabled it to successfully solve ecological problems.

Author Contributions: Conceptualization, J.F. and S.M.-S.; methodology, J.F. and S.M.-S.; software, J.F.; validation, J.F. and S.M.-S.; formal analysis, J.F.; investigation, J.F.; resources, J.F. and S.M.-S.; data curation, J.F. and S.M.-S.; writing-original draft preparation, J.F.; writing-review and editing, J.F. and S.M.-S.; visualization, J.F.; supervision, S.M.-S. All authors have read and agreed to the published version of the manuscript.

Funding: This research received no external funding.

Conflicts of Interest: The authors declare no conflict of interest.

\section{References}

1. Nelson, J.S.; Grande, T.C.; Wilson, M.V.H. Fishes of the World, 5th ed.; Wiley: Hoboken, NJ, USA, 2016; pp. 468-472.

2. Naranji, M.K.; Velamala, G.R.; Sujatha, K. Reproductive biology of female sawcheek scorpionfish, Brachypterois serrulata (Richardson, 1846) (Teleostei; Scorpaenidae) from Visakhapatnam Coast, India. Mar. Life Sci. Technol. 2021, 3, 347-354. [CrossRef]

3. Pavlov, D.A.; Emel'yanova, N.G. Features of reproductive biology in two tropical fish species from the family Scorpaenidae. J. Ichthyol. 2007, 47, 347-360. [CrossRef]

4. Özgül, A.; Lök, A.; Tansel Tanrıkul, T.; Alós, J. Home range and residency of Scorpaena porcus and Scorpaena scrofa in artificial reefs revealed by fine-scale acoustic tracking. Fish. Res. 2019, 210, 22-30. [CrossRef]

5. Hureau, J.C.; Litvinenko, N.I. Scorpaenidae. In Fishes of the North-Western Atlantic and the Mediterranean; Whitehead, P.J.P., Bauchot, M.L., Hureau, J.C., Nielsen, J., Tortonese, E., Eds.; UNESCO: Paris, France, 1986; Volume 3, pp. 1211-1229.

6. Pallaoro, A.; Jardas, I. Food and feeding habits of black scorpionfish (Scorpaena porcus L. 1758) (Pisces, Scorpaenidae) along the Adriatic coast. Acta Adriat. 1991, 32, 895-898. 
7. Ferri, J.; Stagličić, N.; Matić-Skoko, S. The black scorpionfish, Scorpaena porcus (Scorpaenidae): Could it serve as reliable indicator of Mediterranean coastal communities' health? Ecol. Indic. 2012, 18, 25-30. [CrossRef]

8. Fischer, W.; Schneider, M.; Bauchot, M.L. Fiches FAO d' identification des espèces pour les besoins de la pêche. Mediterranée et Mer Noire. Zone de peche 37. Vertebres 1987, 2, 1529.

9. Pashkov, A.N.; Shevchenko, N.F.; Oven, L.S.; Giragosov, V.E.; Kruglov, M.V. Distribution, numbers, and principal population index of Scorpaena porcus under anthropogenic pollution of the Black Sea. J. Ichthyol. 1999, 39, 634-641.

10. La Mesa, M.; Scarcella, G.; Grati, F.; Fabi, G. Age and growth of the black scorpionfish, Scorpaena porcus (Pisces: Scorpaenidae) from artificial structures and natural reefs in the Adriatic Sea. Sci. Mar. 2010, 74, 677-685. [CrossRef]

11. Ferri, J.; Petrić, M.; Matić-Skoko, S. Biometry analysis of the black scorpionfish, Scorpaena porcus (Linnaeus, 1758) from the Eastern Adriatic Sea. Acta Adriat. 2010, 51, 45-53.

12. Harmelin-Vivien, M.L.; Kaim-Malka, R.A.; Ledoyer, M.; Jacob-Abraham, S.S. Food partitioning among scorpaenid fishes in Mediterranean seagrass beds. J. Fish. Biol. 1989, 34, 715-734. [CrossRef]

13. Rafrafi-Nouira, S.; El Kamel-Moutalibi, O.; Boumaïza, M.; Reynaud, C.; Capapé, C. Food and feeding habits of black scorpionfish, Scorpaena porcus (Osteichthyes: Scorpaenidae) from the northern coast of Tunisia (Central Mediterranean). J. Ichthyol. 2016, 56, 107-123. [CrossRef]

14. Aydin, M.; Mazlum, R.E. Feeding ecology of black scorpion fish (Scorpaena porcus Linnaeus, 1758) in SE Black Sea region, (Ordu) Turkey. J. Mar. Biol. Assoc. 2020, 100, 435-444. [CrossRef]

15. Kutsyn, D.N.; Skuratovskaya, E.N.; Chesnokova, I.I. Body size, age structure, growth, and maturation of black scorpionfish Scorpaena porcus (Scorpaenidae) from Southwestern Crimea (Black Sea). J. Ichthyol. 2019, 59, 864-869. [CrossRef]

16. Bradai, N.; Bouain, A. Age et croissance de Scorpaena porcus et Scorpaena scrofa du golfe de Gabes. Bull. Inst. Natl. Sci. Tech. Océanogr Pêche Salammbô 1988, 15, 13-38.

17. Ünsal, N.; Oral, M. A study on the growth and reproduction of black scorpionfish (Scorpaena porcus Linnaeus, 1758) in the Sea of Marmara. Turk. J. Zool. 1996, 20, 303-308.

18. Şahin, C.; Erbay, M.; Kalaycı, F.; Ceylan, Y.; Yeşilçiçek, T. Life-history traits of the black scorpionfish (Scorpaena porcus) in SouthEastern Black Sea. Turk. J. Fish. Aquat. Sci. 2019, 19, 571-584.

19. Jardas, I.; Pallaoro, A. Age and growth of Black Scorpionfish, Scorpaena porcus L., 1758, in the Adriatic Sea. Rapp. Comm. Int. Mer. Medid. 1992, 33, 296.

20. Santana, H.S.; Minte-Vera, C.V. Age and growth of Prochilodus lineatus in a spatially structured population: Is there concordance between otoliths and scales? Environ. Biol. Fishes 2017, 100, 223-235. [CrossRef]

21. Bacha, M.; Aissa, M.; Benmansour, N.; Brylinski, J.; Kélig, M.; Rachid, A. Relationships between age, growth, diet and environmental parameters for anchovy (Engraulis encrasicolus L.) in the Bay of Benisaf (SW Mediterranean, West Algerian coast). Cybium 2010, 34, 47-57.

22. Pennino, M.G.; Coll, M.; Albo-Puigserver, M.; Fernández-Corredor, E.; Steenbeek, J.; Giráldez, A.; González, M.; Esteban, A.; Bellido, J.M. Current and future influence of environmental factors on small pelagic fish distributions in the Northwestern Mediterranean Sea. Front. Mar. Sci. 2020, 7, 622. [CrossRef]

23. Longo, F.; Malara, D.; Stipa, M.G.; Consoli, P.; Romeo, T.; Sanfilippo, M.; Abbate, F.; Andaloro, F.; Battaglia, P. Age, growth and Otolith microstructure of the Spotted Lanternfish Myctophum punctatum Rafinesque 1810. J. Mar. Sci. Eng. 2021, 9, 801. [CrossRef]

24. Bellodi, A.; Massaro, A.; Zupa, W.; Donnaloia, M.; Follesa, M.C.; Ligas, A.; Mulas, A.; Palmisano, M.; Carbonara, P. Assessing thornback ray growth pattern in different areas of Western-Central Mediterranean Sea through a multi-model inference analysis. J. Sea Res. 2022, 179, 102-141. [CrossRef]

25. Blanck, A.; Lamouroux, N. Large-scale intraspecific variation in life-history traits of European freshwater fish. J. Biogeogr. 2007, 34, 862-875. [CrossRef]

26. Ribas, D.; Munoz, M.; Casadevall, M.; de Sola, L.G. How does the northern Mediterranean population of Helicolenus dactylopterus dactylopterus resist fishing pressure? Fish. Res. 2006, 79, 285-293. [CrossRef]

27. Morović, M.; Grbec, B. Physical and Chemical Properties of Seawater. Coastal Sea Quality Control: Project 'Vir-Konavle 2008'; Studies of the Institute of Oceanography and Fisheries: Split, Croatia, 2009; pp. 30-41.

28. Brusca, R.C.; Brusca, G.J. Invertebrates, 2nd ed.; Sinauer Associates: Sunderland, MA, USA, 2003; p. 936.

29. Krebs, C.J. Ecological Methodology; Addison Wesley, Longman Inc.: London, UK, 1994.

30. Pinkas, L.; Oliphant, M.S.; Iversen, I.L.K. Food habits of albacore, bluefin tuna and bonito in California waters. Fish. Bull. 1971, 152, 1-105.

31. Zander, C.D. Feeding ecology of littoral gobiid and blennoid fish of the Banyuls area (Mediterranean Sea). I. Main Food and trophic dimensions of niche and ecotope. Vie Milieu 1982, 32, 10-20.

32. Platell, M.E.; Potter, I.C. Partitioning of food resources amongst 18 abundant benthic carnivorous fish species in marine waters on the lower west coast of Australia. J. Exp. Mar. Biol. Ecol. 2001, 261, 31-54. [CrossRef]

33. Sommerville, E.; Platell, M.E.; White, W.T.; Jones, A.A.; Potter, I.C. Partitioning of food resources by four abundant, co-occurring elasmobranch species: Relationships between diet and both body size and season. Mar. Freshw. Res. 2011, 62, 54-65. [CrossRef]

34. Clarke, K.R.; Gorley, R.N. PRIMER v6: User Manual/Tutorial (Plymouth Routines in Multivariate Ecological Research); PRIMER-E: Plymouth, UK, 2006.

35. Clarke, K.R. Non-parametric multivariate analyses of changes in community structure. Aust. J. Ecol. 1993, 18, 117-143. [CrossRef] 
36. Anderson, M.J.; Gorley, R.N.; Clarke, K.R. PERMANOVA+ for PRIMER: Guide to Software and Statistical Methods; PRIMER-E: Plymouth, UK, 2008.

37. Bernard, D.A. Multivariate analysis as a means of comparing growth in fish. Can. J. Fish. Aquat. Sci. 1981, 38, 233-236. [CrossRef]

38. Munro, J.L.; Pauly, D. A simple method for comparing the growth of fishes and invertebrates. Fishbyte 1983, 1, 5-6.

39. Lowe-Mcconnell, R.H. Estudos Ecológicos de Comunidades de Peixes Tropicais; EDUSP: São Paulo, Brazil, $1999 ;$ p. 534.

40. Damalas, D.; Maravelias, C.D.; Katsanevakis, S.; Karageorgis, A.P.; Papaconstantinou, C. Seasonal abundance of non-commercial demersal fish in the eastern Mediterranean Sea in relation to hydrographic and sediment characteristics. Estuar. Coast. Shelf. Sci. 2010, 89, 107-118. [CrossRef]

41. Castriota, L.; Falautano, M.; Finoia, M.G.; Campo, D.; Scarabello, M.P.; Andaloro, F. Temporal variations in the diet of pearly razorfish Xyrichtys novacula (Osteichthyes: Labridae). J. Fish. Biol. 2010, 76, 1626-1639. [CrossRef]

42. Lek, E.; Fairclough, D.V.; Platell, M.E.; Clarke, K.R.; Tweedley, J.R.; Potter, I.C. To what extent are the dietary compositions of three abundant, co-occurring labrid species different and related to latitude, habitat, body size and season? J. Fish. Biol. 2011, 78, 1913-1943. [CrossRef] [PubMed]

43. La Mesa, G.; La Mesa, M.; Tomassetti, P. Feeding habits of the Madeira rockfish Scorpaena maderensis from central Mediterranean Sea. Mar. Biol. 1997, 150, 1313-1320. [CrossRef]

44. Koca, H.U. A study on the determination of some parameters of the scorpion fish (Scorpaena porcus Linnaeus, 1758) caught by bottom nets in the area of Sinop in terms of fishery biology. Turk. J. Veter. Anim. Sci. 2003, 26, 65-69.

45. Silvestri, R.; Voliani, A.; Zucchi, A. Nota sulla biologia di Scorpaena porcus Linneo, 1758 nel Mar Ligure meridionale. Biol. Mar. Medit. 2002, 9, 813-817.

46. Atkinson, D. Temperature and organism size-A biological law for ectotherms? Adv. Ecol. Res. 1994, 25, 1-58. [CrossRef]

47. Kozłowski, J.; Czarnołeski, M.; Danko, M. Can optimal resource allocation models explain why ectotherms grow larger in cold? Integr. Comp. Biol. 2004, 44, 480-493. [CrossRef]

48. Lek, E.; Fairclough, D.V.; Hall, N.G.; Hesp, S.A.; Potter, I.C. Do the maximum sizes, ages and patterns of growth of three reef-dwelling labrid species at two latitudes differ in a manner conforming to the metabolic theory of ecology? J. Fish. Biol. 2012, 81, 1936-1962. [CrossRef] 